\title{
Cutaneous metastasis as the first sign of renal cell carcinoma - crossroad between literature analysis and own observations
}

\author{
Krzysztof Balawender ${ }^{1,2}$, Rafał Przybyła1 ${ }^{1}$, Stanisław Orkisz², Agata Wawrzyniak², Dariusz Boroń ${ }^{3,4}$,
} Beniamin O. Grabarek ${ }^{3,4}$

${ }^{1}$ Clinical Department of Urology and Urological Oncology, Municipal Hospital, Rzeszow, Poland

${ }^{2}$ Morphological Sciences Department of Human Anatomy Institute of Medical Sciences, Medical College of Rzeszow University, Rzeszow, Poland

${ }^{3}$ Department of Gynecology and Obstetrics with Gynecologic Oncology, Ludwik Rydygier Memorial Specialized Hospital, Krakow, Poland

${ }^{4}$ Department of Histology, Cytophysiology and Embryology in Zabrze, University of Technology, Faculty of Medicine in Katowice, Poland Adv Dermatol Allergol 2022; XXXIX (3): 553-558 DOI: https://doi.org/10.5114/ada.2021.108275

\begin{abstract}
Introduction: Metastatic disease can be observed in nearly $25 \%$ of all renal cell carcinoma cases (RCC). This can present in the skin as a late symptom of the disease or as a manifestation of an undetected, asymptomatic RCC. Aim: To review the literature and present a case study of cutaneous metastasis in primary genitourinary malignancy, especially RCC in order to broaden the related knowledge.

Material and methods: The first stage of our work was focused on presenting the results of the literature review about cutaneous metastasis in the patients with renal cell carcinoma. Next, taking into account that this type of metastasis associated with RCC is relatively rare, we have decided to present a patient aged 68 with incidentally detected skin metastases of RCC located on the scalp.

Results: It was diagnosed as a primary manifestation of advanced disease. Computed tomography scans showed a solid mass in the left kidney. Following surgical excision of the skin lesion, a left-side nephrectomy was performed. Conclusions: Cutaneous metastases of RCC present an unfavourable prognosis, however, remission is possible subsequent to early diagnosis and appropriate surgical excision.
\end{abstract}

Key words: renal cell carcinoma, cutaneous metastasis, case report, literature review.

\section{Introduction}

The incidence of renal cell carcinoma (RCC) is the highest in Western population (2-3\% of all cancer types). In kidney cancer, 80-90\% of all cases are clear cell carcinomas. Cutaneous metastatic (CM) can be observed in nearly $25 \%$ of all RCC cases. At diagnosis, $16 \%$ of patients with RCC are found to have metastases and, therefore, present a poor prognosis (cancer specific survival (CSS) hazard ratio (HR) 33.23; 95\% Cl: 28.18-39.18; $p<0.001$ ) $[1,2]$. The most common locations for metastasis of RCC are the lungs (50\%), bones (33\%), lymph nodes (6-11\%), liver (8\%), and adrenal glands and brain (3\%) [3]. Cutaneous metastasis of RCC is rare and usually related to a late symptom of the disease. These metastases de- velop within 36 months after the primary malignancy is initially diagnosed (1-177 months), but occasionally skin metastases are the manifestation of an undetected, asymptomatic RCC [4]. One meta-analysis reported the overall incidence of cutaneous metastases in all tumour types of 5.3\% [5]. Other recent report suggests this prevalence to be from $1 \%$ to $4.3 \%$ [6].

The case presented here is of a human with scalp metastasis of clear RCC, found to be a primary manifestation of advanced cancer [7].

\section{Aim}

The study aimed to review the literature and present a case study of cutaneous metastasis in primary genito-

Address for correspondence: Krzysztof Balawender MD, PhD, Clinical Department of Urology and Urological Oncology, Municipal Hospital, 4 Rycerska St, 35-241 Rzeszow, Poland, e-mail: krzysztofbalawender2@gmail.com Received: 29.06.2021, accepted: 11.07.2021. 
urinary malignancy, especially RCC in order to broaden the related knowledge.

\section{Material and methods}

In the first stage of our work, the review of the literature about cutaneous metastasis in primary genitourinary malignancy, especially renal cell carcinoma was performed. Pubmed, Science Direct and Web of Science were used for the analyses.

The work was performed according to the guidelines of the Declaration of Helsinki. Because this is a case retrospective study, the Opinion of the Bioethical Committee was not required. Considering that CM in RCC is relatively rare (the first case in 10 years in our hospital), we decided to present a case report of a man aged 68 with an incidentally detected skin lesion located on the scalp. Little was known about the patient as he had not been under medical supervision for over 10 years and therefore had no medical history. We only knew that he was a heavy smoker. The hairdresser found a small lump on the scalp during a haircut. Upon physical examination, a $10-\mathrm{mm}$, well-delineated, painless nodule in the hairy scalp was identified. Surgical excision of the tumour was performed under local anaesthesia, with a margin of healthy skin.

\section{Results}

This review analysis showed that genitourinary malignancies metastasised to the skin as listed in Table 1. Analysis of recent reports, based on case report analyses from Science Direct and Web of Science (2000-2019) showed that $63 \%$ of the cases involved patients with a secondary cutaneous metastasis who underwent a surgical treatment of kidney tumour in the past. As many as 37\% of patients were diagnosed with skin metastases as a primary manifestation of cancer (Table 2). Based on the analysis of up-to-date case reports, CM of RCC are most often found on the face ( $43 \%$ of patients) followed by the scalp (30\% of patients) and the neck ( $7 \%$ of patients). Table 3 shows the metastatic sites of the skin.

In the histopathological analysis the lesion was described as a clear cell carcinoma (Figure 1) and determined to be a renal cancer metastasis. The tumour was excised with a minimum $2 \mathrm{~mm}$ surgical margin. A posi- tive result for CD10 was noted in immunohistochemical staining. The patient underwent computed tomography (CT) of the abdominal cavity and chest. It showed the primary source of metastasis to the skin, and in the superior pole of the left kidney a partially exophytic, solid mass measuring $60 \times 65 \mathrm{~mm}$ and lacking lymphadenopathy in the retroperitoneal space. A left-side nephrectomy was performed and clear RCC was confirmed via histopathological analysis (Figure 1). The image demonstrates the optically clear tumour cells with uniform small nuclei without nucleolar ranged in an alveolar pattern (Figures $1 \mathrm{~B}, \mathrm{C})$. Slightly irregular nuclear contours; nucleoli visible (Figure $1 \mathrm{E}$ ). Nuclei are uniform and small with inconspicuous nucleoli at this power (Figure 1 A) Necrotic changes are visible (Figure $1 \mathrm{D})$.

According to the Memorial Sloan-Kettering Cancer Centre (MSKCC) Risk Group, this case was described as the intermediate risk group. A clinical and radiological follow up at 30 months did not show tumour recurrence.

\section{Discussion}

RCC has been classified as the most common kidney tumour and its morbidity has increased from 1.5\% to $5.9 \%$ annually [8]. Cutaneous metastases are seen in approximately $2.8-6.8 \%$ of RCC cases. According to the statistics, skin metastasis had been observed before a primary tumour in $16-21 \%$ of cases. However, the prevalence has been reported as high as $26 \%[6,9]$. It is said that cutaneous metastases might be the first signs of clinically silent visceral cancer [10]. Analysis of recent reports shows that the mean period of time between a nephrectomy and diagnosed cutaneous metastasis was 4.5 years, with the longest period reported to be 19 years [9]. These reports also revealed that $94 \%$ of cases were male. In the present case, RCC was incidentally found before the primary tumour was detected in the kidney during a visit to a hairdressing salon.

Paolino et al. described the results of 118 reports for 123 cases with alopecia neoplastic from visceral tumours. It was observed that the most common place of the primary tumour was the gastrointestinal tract, followed by breast, kidney, lung, thyroid, uterus, central nervous system, and liver [11]. The authors indicated that in the patients with localized scarring alopecia one always ought to remember about metastatic skin disease [11].

Table 1. Localization of new cutaneous lesions in groups of patients with primary genitourinary malignancy

\begin{tabular}{lcccc}
\hline Primary cancer & $\begin{array}{c}\text { Percent of skin metastases } \\
\text { (2014) ref [25] }\end{array}$ & $\begin{array}{c}\text { Percent of skin metastases } \\
\text { (2004) ref [27] }\end{array}$ & $\begin{array}{c}\text { Percent of skin metastases } \\
\text { (1993) ref [29] }\end{array}$ & $\begin{array}{c}\text { Common presenting } \\
\text { location }\end{array}$ \\
\hline Kidney & 2.7 & 3.4 & 1.4 & Head-neck \\
\hline Bladder & 0.2 & 0.84 & 0 & Abdomen \\
\hline Prostate & 0.5 & 0.36 & 0 & Abdomen \\
\hline Testes & 0.5 & 0.4 & Head-neck, chest \\
\hline
\end{tabular}


Table 2. List of RCC case reports with skin metastasis published between 2000 and 2019 (based on analyses from Science Direct and Web of Science)

\begin{tabular}{|c|c|c|c|c|c|c|}
\hline Author & 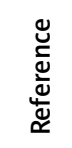 & 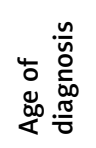 & 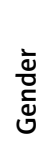 & $\begin{array}{l}\text { Skin metastases } \\
\text { as the first } \\
\text { presentation of } \\
\text { RCC }\end{array}$ & $\begin{array}{l}\text { Mets after } \\
\text { kidney surgery } \\
\text { for RCC }\end{array}$ & $\begin{array}{l}\text { Time period between } \\
\text { primary kidney tumour } \\
\text { diagnosis and skin } \\
\text { metastases }\end{array}$ \\
\hline Bjurlin et al. & {$[28]$} & 40 & M & Yes & & \\
\hline Gonzales et al. & [29] & 77 & M & Yes & & \\
\hline Soares et al. & {$[30]$} & 70 & M & & Yes & 5 months \\
\hline Cabrera-Beyrouti et al. & {$[31]$} & 87 & M & Yes & & \\
\hline Bhatia et al. & {$[32]$} & 63 & M & Yes & & \\
\hline Navarrete-Gutiérrez et al. & [33] & 51 & M & Yes & & \\
\hline Nakano et al. & {$[34]$} & 72 & M & & Yes & 19 years \\
\hline Boaz et al. & {$[35]$} & 38 & M & & Yes & 1 year \\
\hline Jatti et al. & {$[36]$} & 60 & M & & Yes & 5 months \\
\hline Riter et al. & {$[37]$} & 53 & M & & Yes & No information \\
\hline Porter et al. & {$[38]$} & 36 & M & Yes & & \\
\hline Lim et al. & [39] & 86 & M & & Yes & 4 years \\
\hline Fernandez-Rueda et al. & {$[40]$} & 80 & M & & Yes & 2 years \\
\hline Pritchyk et al. & {$[41]$} & 70 & M & & Yes & 5 years \\
\hline Rajasekharan et al. & {$[42]$} & 55 & $M$ & Yes & & \\
\hline Tadashi et al. & {$[43]$} & 84 & M & & Yes & 9 years \\
\hline Arrabal-Polo et al. & {$[44]$} & 73 & M & & Yes & 10 years \\
\hline Ferhatoglu et al. & {$[45]$} & 40 & $\mathrm{~F}$ & & Yes & 14 months \\
\hline Kandemir et al. & [46] & 53 & M & & Yes & 3 years \\
\hline Cui et al. & {$[47]$} & 86 & M & Yes & & \\
\hline Mirza et al. & {$[48]$} & 41 & M & Yes & & \\
\hline Errami et al. & [49] & 64 & M & & Yes & 3 years \\
\hline Singh et al. & {$[50]$} & 51 & M & & Yes & 11 years \\
\hline Abbasi et al. & {$[51]$} & 42 & M & & Yes & 1 month \\
\hline Chauhan et al. & {$[52]$} & 57 & M & Yes & & \\
\hline Opper et al. & {$[53]$} & 63 & M & & Yes & No information \\
\hline Pan et al. & {$[54]$} & 63 & M & Yes & & \\
\hline García Torrelles et al. & [55] & 60 & M & & Yes & 5 years \\
\hline Soda et al. & {$[56]$} & 78 & M & Yes & & \\
\hline Snow et al. & {$[57]$} & 69 & $\mathrm{~F}$ & & Yes & 6 years \\
\hline Kotak et al. & {$[58]$} & 64 & M & & Yes & 6 months \\
\hline
\end{tabular}

$M$ - male, F-female.

The most frequent site for skin metastasis of RCC has not been found yet. Dorairajan et al. indicated that in $50 \%$ of RCC cases, the cutaneous metastasis was diagnosed on the scalp [12]. In turn, observations made by Koga et al. suggested that $40 \%$ of skin metastases cases occurred on the trunk, and only $25 \%$ on the scalp [13]. Additionally, up to $75 \%$ of patients had secondary metastases in at least one other site, most commonly in visceral organs, such as the lungs and liver [14]. Distant organ metastases from the primary focus most often occur through lymphangiogenesis. The second way to form distant metastases is the vascular route associated with the increased process of angiogenesis, which is observed in neoplasms [15].

In our case, the metastatic skin lesion was about $10 \mathrm{~mm}$, with red-purple colour, and a nodular type. Skin metasta- 
sis of RCC may be confused with haemangioma, pyogenic granuloma, Kaposi's sarcoma, infected skin cysts, or skin lymphoma, and for that reason, we should consider those lesions in the differential diagnosis [16, 17].

The large acinar structures formed from clear RCC have layers of clear cells with central glassy eosinophilic secretions (Figures 1 A-E). Immunohistochemically, 60\%

Table 3. Metastatic sites of the skin in RCC patients based on up-to-date case reports published between 2000 and 2019

\begin{tabular}{|c|c|c|c|c|}
\hline Location & & Number & $\%$ & References \\
\hline \multirow[t]{5}{*}{ Face } & Lips & & & {$[26,34,37,45,56]$} \\
\hline & Eyelids & & & {$[27,29]$} \\
\hline & Cheeks & 16 & 43 & {$[14,28,32,37]$} \\
\hline & Nose & & & {$[30,40]$} \\
\hline & Chin & & & {$[33,36,38]$} \\
\hline Scalp & & 11 & 30 & $\begin{array}{c}{[14,35,38,43,46,47} \\
49,52,53,54,55]\end{array}$ \\
\hline Neck & & 7 & 19 & {$[30,37,41,42,44,50,51]$} \\
\hline Extremities & & 3 & 8 & {$[13,35,50]$} \\
\hline
\end{tabular}

of RCC tumour cell skin lesions express vimentin, epithelial membrane antigen (EMA), carcinoembryonic antigen (CEA), CD10, RCC-Ma, and keratins [3]. Their development became possible thanks to the development of methods and techniques of molecular biology. Currently, there are databases available containing sets of genes and their coding proteins characteristic for a given tumour [18].

The prognosis of the patients with RCC metastases is unfavourable. In general, the five-year survival rate for the patients with RCC solitary metastases is 10-13\% [19]. The average life expectancy usually is less than 6 to 12 months from diagnosis. It should be noted that 5-year survival increases by approximately $30-45 \%$ in patients with RCC and metastases who underwent metastasectomy [20].

The treatment recommendation in skin metastases of RCC is surgery (nephrectomy and metastasectomy). Surgery in advanced patients may be completed by tyrosine-kinase inhibitor therapy. It has also been suggested that radiotherapy with adjuvant chemotherapy could have good results. Gay et al. noticed that complete remission was observed in a patient with a solitary skin metastasis after both sorafenib therapy and radiotherapy [21]. Lyon et al. showed that in patients with a complete metastasectomy, in comparison to patients without,
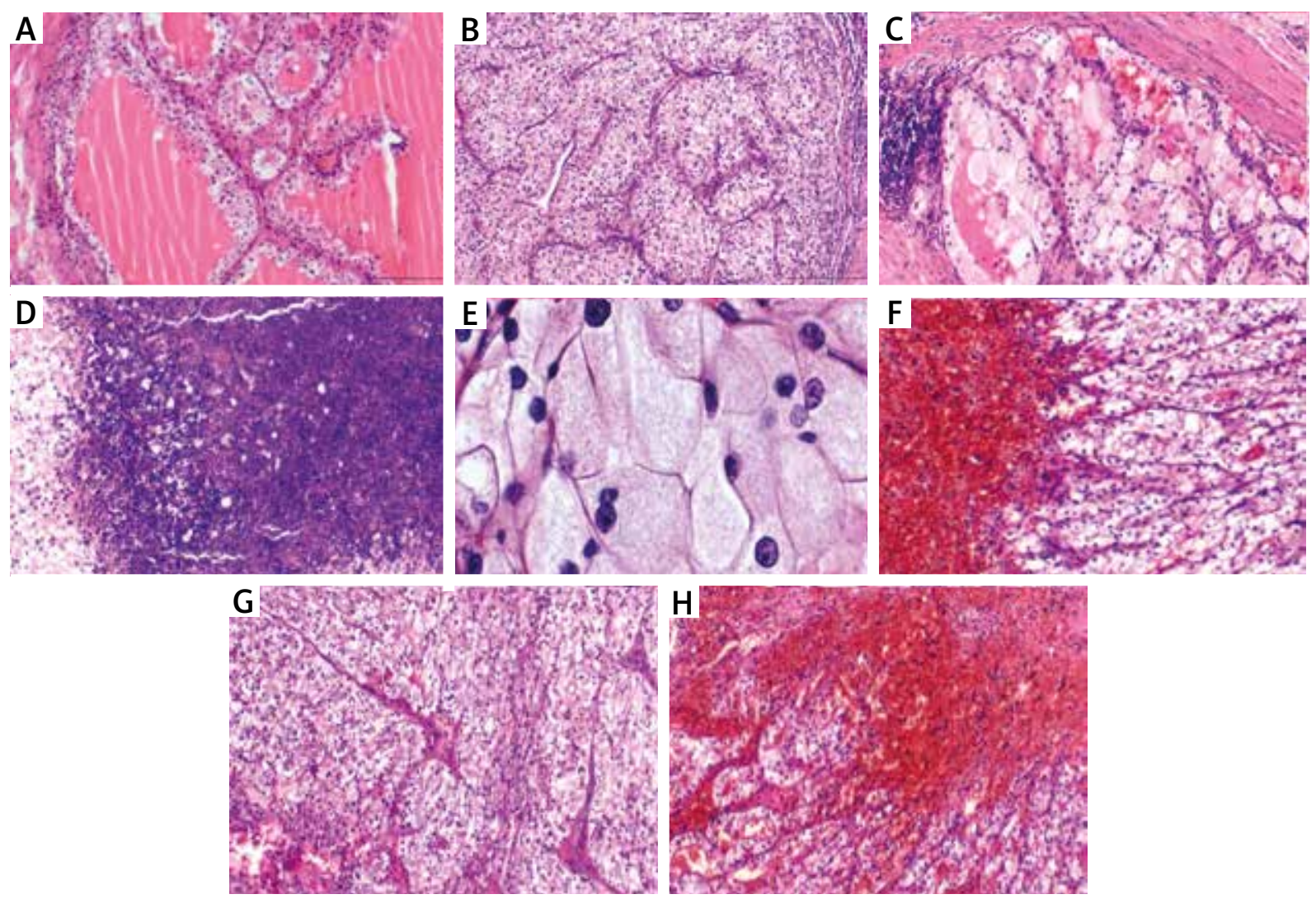

Figure 1. The micrograph of a clear cell renal cell carcinoma haematoxylin and eosin (H\&E) staining obtained from the described patient. Skin metastasis of renal cell carcinoma H\&E sections (F-H). Scale bar: A-D and F-H $200 \mu \mathrm{m} ; \mathrm{E}-$ $50 \mu \mathrm{m}$. The samples were analysed morphologically and photographed under an Olympus BX43 light microscope equipped with an Olympus SC50 digital camera 
2-year CSS was significantly greater, what was related with reduced probability of death due to RCC $(p<0.001)$ [20]. Ouzaid et al. observed lower mortality in patients who underwent metastasectomy compared to those who did not [22, 23]. In turn, Tosco et al. suggested that the Leuven-Udine classification ought to be used in analysis of the results of surgically treated patients [24]. Summarizing, cutaneous metastases of RCC are indicative of a poor prognosis, but disease-free follow up is possible after early diagnosis and the appropriate surgical excision. Based on the analysis of up-to-date case reports, cutaneous metastases of RCC are most often found on the face. Relying on systematic reviews, nephrectomy and complete metastasectomy are viable therapeutic options, resulting in significantly improved CSS and reduced likelihood of death from RCC. Furthermore, the presented case highlights the importance of oncological diagnostics such as multiple detailed physical examinations as they are critical to positive patient outcomes to supplement the continuous development of new imaging techniques and laboratory diagnostics.

\section{Acknowledgments}

The study was conducted according to the guidelines of the Declaration of Helsinki. Informed consent was obtained from all subjects involved in the study. The data used to support the findings of this study are included in the article. The data will not be shared due to third-party rights and commercial confidentiality.

\section{Conflict of interest}

The authors declare no conflict of interest.

\section{References}

1. Keegan KA, Schupp CW, Chamie K, et al. Histopathology of surgically treated renal cell carcinoma: Survival differences by subtype and stage. J Urol 2012; 188: 391-7.

2. Walton J, Li J, Clifton M, et al. Metastatic clear cell renal cell carcinoma to the forearm without identifiable primary renal mass. Urol Case Rep 2019; 27: 100989.

3. de Paula TA, da Silva PSL, Berriel LGS. Renal cell carcinoma with cutaneous metastasis: case report. J Bras Nefrol 2010; 32: 213-5.

4. Jour G, Al-Rohil RN. Cutaneous metastases. Diagnostic Histopathol 2019; 25: 87-95.

5. Bujons A, Pascual X, Martínez R, et al. Cutaneous metastases in renal cell carcinoma. Urol Int 2008; 80: 111-2.

6. Choate EA, Nobori A, Worswick S. Cutaneous metastasis of internal tumors. Dermatol Clin 2019; 37: 545-54.

7. Riley DS, Barber MS, Kienle GS, et al. CARE guidelines for case reports: explanation and elaboration document. J Clin Epidemiol 2017; 89: 218-35.

8. Semeniuk-Wojtaś A, Stec R, Szczylik C. Are primary renal cell carcinoma and metastases of renal cell carcinoma the same cancer. Urol Oncol 2016; 34: 215-20.
9. Handa U, Kundu R, Dimri K. Cutaneous metastasis: a study of 138 cases diagnosed by fine-needle aspiration cytology. Acta Cytol 2017; 61: 47-54.

10. Paolino G, Lido P, Bei R, Polisca P. Undifferentiated metastatic renal cell carcinoma presenting as a cutaneous nodular lesion. Turk J Urol 2015; 41: 228-30.

11. Paolino G, Pampena R, Grassi S, et al. Alopecia neoplastica as a sign of visceral malignancies: a systematic review. J Eur Acad Dermatol Venereol 2019; 33: 1020-8.

12. Dorairajan LN, Hemal AK, Aron M, et al. Cutaneous metastases in renal cell carcinoma. Urol Int 1999; 63: 164-7.

13. Koga S, Tsuda S, Nishikido M, et al. Renal cell carcinoma metastatic to the skin. Anticancer Res 2000; 20: 1939-40.

14. Benhayoune K, El Fatemi H, El Fassi J, et al. Scrotal skin metastases of renal cell carcinoma: a case report. Case Rep Clin Med 2015; 4: 93-6.

15. Badiu CD, Aungurenci A, Manea CA, et al. Axillary skin metastasis of renal cell carcinoma - case report. Int J Surg Case Rep 2017; 34: 74-6.

16. Urakçi Z, Kaplan MA, Küçüköner M, et al. Renal cell carcinoma presenting with cutaneous metastasis: a case report. Türk Onkol Derg 2013; 28: 163-6.

17. Habermehl G, Ko J. Cutaneous metastases: a review and diagnostic approach to tumors of unknown origin. Arch Pathol Lab Med 2019; 143: 943-7.

18. Meiri E, Meuller WC, Rosenwald S, et al. A second-generation microRNA-based assay for diagnosing tumor tissue origin. Oncologist 2012; 17: 801-12.

19. Greco F. Metastatic renal cell carcinoma: an invincible enemy? Eur Urol 2013; 63: 655-6.

20. Hofmann HS, Neef H, Krohe K, et al. Prognostic factors and survival after pulmonary resection of metastatic renal cell carcinoma. Eur Urol 2005; 48: 77-81.

21. Gay HA, Cavalieri R, Allison RR, et al. Complete response in a cutaneous facial metastatic nodule from renal cell carcinoma after hypofractionated radiotherapy. Dermatol Online J 2007; 13: 6.

22. Lyon TD, Thompson RH, Shah PH. Complete surgical metastasectomy for renal cell carcinoma in the post-cytokine era. J Urol 2019; 8: 101097.

23. Ouzaid I, Capitanio U, Staehler M, et al. Surgical metastasectomy in renal cell carcinoma: a systematic review. Eur Urol Oncol 2019; 2: 141-9.

24. Tosco L, Van Poppel H, Frea HB, et al. Survival and impact of clinical prognostic factors in surgically treated metastatic renal cell carcinoma. Eur Urol 2013; 63: 646-52.

25. Wong CY, Helm MA, Helm TN, et al. Patterns of skin metastases: a review of 25 years' experience at asingle cancer center. Int J Dermatol 2014; 53: 56-60.

26. Mueller TJ, Wu H, Richard E, et al. Cutaneous metastases from genitourinary malignancies. Urology 2004; 63: 1021-6.

27. Lookingbill DP, Spangler N, Helm KF. Cutaneous metastases in patients with metastatic carcinoma: a retrospective study of 4020 patients. J Am Acad Dermatol 1993; 29: 228-36.

28. Bjurlin MA, Bhalani V, Jordan MD, Hollowell C. Solitary facial cutaneous metastasis as the primary presentation of a small renal cell carcinoma. Urology 2010; 76: 1377-8.

29. Gonzalez F, Abalo-Lojo JM, Suarez-Peńaranda JM, CaneiroGómez J. Eyelid metastasis as the initial presentation of a renal cell carcinoma. Urology 2015; 85: 35-6.

30. Soares GH, Lallas A, Lombardi M, et al. Cutaneous metastasis of renal carcinoma. J Am Acad Dermatol 2015; 72: 45-6. 
31. Cabrera-Beyrouti R, Campos-Mollo E, Rico-Santos E, et al. Eyelid metastasis as first presentation of renal cell carcinoma. Arch Soc Esp Oftalmol 2017; 92: 547-51.

32. Bhatia S, Ng S, Hodder SC. Metastatic cutaneous head and neck renal cell carcinoma with no known primary: case report. Br J Oral Maxillofac Surg 2010; 48: 214-5.

33. Navarrete-Gutiérrez G, Fuentes-Valencia A, Salaverría-Cáceres J, Vela-Jiménez G. Metastasis to scalp of clear cell carcinoma. Actas Urol Espańol 2010; 34: 923-4.

34. Nakano H, Naito K, Suzuki S, et al. Metastatic renal cell carcinoma in the cheek: report of a case. J Oral Maxillofac Surg Med Pathol 2013; 25: 291-3.

35. Boaz RJ, Vig T, Tirkey AJ, et al. Cutaneous metastasis of renal cell carcinoma masquerading as an infected sebaceous cyst. J Stomatol Oral Maxillofac Surg 2018; 119: 145-7.

36. Jatti D, Puri G, Aravinda K, Dheer DS. An atypical metastasis of renal clear cell carcinoma to the upper lip: a case report. J Oral Maxillofac Surg 2015; 73: 371.e1-6.

37. Riter HG, Ghobrial IM. Renal cell carcinoma with acrometastasis and scalp metastasis. Mayo Clin Proc 2004; 79: 76.

38. Porter NA, Anderson LA, Al-Dujaily S. Renal cell carcinoma presenting as a solitary cutaneous facial metastasis: case report and review of the literature. Int Semin Surg Oncol 2006; 3: 27.

39. Lim C, Chan R, Regan W. Renal cell carcinoma with cutaneous metastases. Australas I Dermatol 2005; 46: 158-60.

40. Fernández-Rueda P, Ruiz-López P, Ramírez-Negrín MA, et al. Cutaneous metastasis of renal cell carcinoma: a case report and review of the literature. Gac Med Mex 2015; 151: 497501.

41. Pritchyk KM, Schiff BA, Newkirk KA, et al. Metastatic renal cell carcinoma to the head and neck. Laryngoscope 2002; 112: 1598-602.

42. Rajasekharan P, Kavishwar VS, Butle P. Cutaneous metastasis from silent renal cell carcinoma. J Postgrad Med 2004; 50: 287-8.

43. Tadashi T. Cutaneous metastasis of renal cell carcinoma: a report of two cases. Int J Clin Exp Pathol 2012; 5: 175-8.

44. Arrabal-Polo MA, Arias-Santiago SA, Aneiros-Fernandez J, et al. Cutaneous metastases in renal cell carcinoma: a case report. Cases J 2009; 2: 7948

45. Ferhatoglu MF, Senol K, Filiz Al. Skin metastasis of renal cell carcinoma: a case report. Cureus 2018; 10: e3614.

46. Kandemir NO, Barut F, Yılmaz K, et al. Renal cell carcinoma presenting with cutaneous metastasis: a case report. Case Rep Med 2010; 2010: 913734.

47. Cui $\mathrm{P}$, Cong $\mathrm{X}$, Yin J, et al. Metastases to the nose from clear cell renal cell carcinoma: a case report. Medicine 2019; 98: e14012.

48. Mirza R, Ellsworth S, King J, et al. Cutaneous metastasis of renal cell carcinoma: fine needle aspiration provides rapid diagnosis. Clin Case Rep 2019; 7: 218-21.

49. Errami M, Margulis V, Huerta S. Renal cell carcinoma metastatic to the scalp. Rare Tumors 2016; 8: 6400.

50. Singh A, Mohan G, Chaturvedi S, Khan SA. Cytodiagnosis of a cutaneous clear cell malignancy: metastatic renal cell carcinoma on Chin. J Clin Diagn Res 2016; 10: ED12-4.

51. Abbasi F, Alizadeh M, Noroozinia F, Moradi A. Cutaneous metastasis of bilateral renal cell carcinoma. J Pak Med Assoc 2013; 63: 111-3.

52. Chauhan A, Ganguly M, Nath P, Chowdhary GS. Cutaneous metastasis to face and neck as a sole manifestation of an unsuspected renal cell carcinoma. Int I Dermatol 2011; 50: 81-4.
53. Opper B, Elsner P, Ziemer M. Cutaneous metastasis of renal cell carcinoma. Am J Clin Dermatol 2006; 7: 271-2.

54. Pan D, Niall O, Sharma H, Gya D. Isolated scalp nodule in patient with undiagnosed RCC. Sci World J 2006; 6: 2430-2.

55. García Torrelles M, Beltrán Armada JR, Verges Prosper A, et al. Metástasis cutánea de carcinoma de células renales. Actas Urol Esp 2007; 31: 556-8.

56. Soda R, Vidolin, AP, Bianchi L, Chimenti S. A 2-year history of an asymptomatic scalp nodule - quiz case. Arch Dermatol 2003; 139: 1497-502.

57. Snow S, Madjar D, Reizner G, et al. Renal cell carcinoma metastatic to the scalp: case report and review of the literature. Dermatol Surg 2001; 27: 192-4.

58. Kotak A, Merrick G. Presentation of metastatic renal cell carcinoma as a lip lesion. J Surg Case Rep 2014; 2014: rju083. 